\title{
Physiological Characters Bacillus sp. on Rhizosphere and Roots of Banana (Musa paradisiaca L.)
}

\author{
Amirah Djohan $^{1 *}$, Tutik Kuswinanti ${ }^{2}$, Baharuddin ${ }^{2}$ and Andi Nasruddin ${ }^{2}$ \\ ${ }^{1}$ Doctoral Degree Program of Agricultural Science in Faculty of Agriculture, Hasanuddin \\ University, Makassar 90245 Indonesia \\ ${ }^{2}$ Plant Pests and Diseases, Faculty of Agriculture, Hasanuddin University Makassar, \\ Indonesia \\ *Corresponding author
}

\begin{tabular}{|c|}
\hline Keywords \\
\hline $\begin{array}{l}\text { Rhizosphere, Roots, } \\
\text { Banana, IAA, } \\
\text { Fusarium wilt, } \\
\text { Bacillus }\end{array}$ \\
\hline Article Info \\
\hline $\begin{array}{l}\text { Accepted: } \\
18 \text { January } 2020 \\
\text { Available Online: } \\
10 \text { February } 2020\end{array}$ \\
\hline
\end{tabular}

A B S T R A C T

\begin{abstract}
Banana (Musa paradisiaca L.) as famous tropical fruit around the world. The one important and destructive disease of banana is Fusarium wilt caused Fusarium oxysporum f.sp. cubense ( $F o c$ ). Foc as soil-borne pathogens and movement of pathogen through the rhizome and water, capable survive in waste crops at the field. The purpose research is to study physiological character of Bacillus sp. such as : ability of bacteria produced IAA (Indole Acetic Acid), gibberelin (GA3), ability phosphate solubilizing and produce salicylic acid as biological control against Foc. The research was conducted from March to November 2018 located in The Agricultural Biotechnology Laboratory, Center of Research Hasanuddin University, Makassar Indonesia. The result was showed Bacillus sp. at PAA 2 produced the highest concentration of IAA in the range approximately $3.26 \mathrm{mgl}^{-}$ ${ }^{1}$, followed by PAA $3\left(2.67 \mathrm{mgl}^{-1}\right)$. However, PUA and PKT 3 isolates produced the lowest IAA with a value of $1.093 \mathrm{mgl}^{-1}$ and $1.037 \mathrm{mgl}^{-1}$. Based on the analysis results was showed that the highest concentration of GA3 at PAA $3\left(4.17 \mathrm{mgl}^{-1}\right)$, followed by PBT $\left(4.16 \mathrm{mgl}^{-1}\right)$ and PMT $1\left(4.15 \mathrm{mgl}^{-1}\right)$ while the lowest concentration of GA3 was produced by PUA $\left(4.03 \mathrm{mgl}^{-1}\right)$. Based on the results showed that PBT isolates containing Bacillus sp. from the soil giving highest number in phosphate solubilizing $\left(10.89 \mathrm{mgl}^{-1}\right)$, followed by PUA 2 $\left(8.96 \mathrm{mgl}^{-1}\right)$ and PMT $\left(8.47 \mathrm{mgl}^{-1}\right)$. The lowest result in phosphate solubilizing showed at PAA $3\left(4.19 \mathrm{mgl}^{-1}\right)$. Based on the result, the concentration of Bacillus sp. the highest was found in PAA $3\left(9.42 \mathrm{mgl}^{-1}\right)$, followed by PMT $\left(7.79 \mathrm{mgl}^{-1}\right)$ and PKT1 $\left(6.13 \mathrm{mgl}^{-1}\right)$. The lowest salicylic acid concentration was shown by PKA $3\left(3.39 \mathrm{mgl}^{-1}\right)$. The presence Bacillus sp. as endophytic microbe living at rhizosphere and roots of banana giving important information for management Foc.
\end{abstract}

\section{Introduction}

Banana (Musa paradisiaca L.) is famous tropical fruit in Indonesia, as important food in tropical and subtropical areas around the world. Few years ago in the world wide, banana market opportunities are still large enough for the domestic and foreign markets. Domestic bananas consumption reaches $16 \mathrm{~kg}$ per capita per year, which continues 
increasing by around $5.96 \%$ per year. In addition, Indonesian banana demand from abroad continues increasing especially from the middle East and East Asia (Nurcahyani et al., 2018; Hermanto et al., 2013). As the center of banana production, South Sulawesi has opportunity improving local farmers income and community services. At the moment, production bananas in South Sulawesi decreased because presence wilt disease by Fusarium oxysforum f.sp. cubense (Foc) attacked banana plantation. The pathogens causing wilt as important major diseases at banana plantations around the world (Jumjunidang et al., 2005; Pan et al., 2008; Fourie et al., 2009). Fusarium is a complex genus of ascomycete fungi that consists of plant pathogens of agricultural relevance. Controlling Fusarium infection in crops that leads to substantial yield losses is challenging. These economic losses along with environmental and human health concerns over the usage of chemicals in attaining disease control are shifting focus toward the use of biocontrol agents for effective control of phytopathogenic Fusarium spp. (Harper, 1950; Khan et al., 2018; Deltour et al., 2017; Warman and Aitken, 2018).

Foc as soil-borne pathogens and movement of pathogen through the rhizome and water, capable survive in waste crops at the field. Management presence of Foc is largely restricted to excluding the pathogen from non-infested areas and using resistant cultivars where pathogen is established. Foc at banana plantation cause disease in all of banana stage development. The pathogens is very difficult to control, because the complexiticy of the pathogen (consisting of many races and ability survive in soil). The pathogenic fungi can persist in a period of 40 years without its host plant (Akila et al., 2011). The effective biological, chemical and cultural measures not yet available.
According to Saravanan et al., (2004); Svabava and Lebeda (2005) reported that few species of bacteria such as Pseudomonas fluorescens as alternative biological agent control Foc by in vitro selection. Pan et. al., (2008) state the possibility control Foc used endophytic bacterium Burkholderia cepacia. This methods will improve plant health and safety environment.

Bacillus sp. is a gram-positive bacteria that lives mostly in the soil. Bacillus is one genus of antagonistic bacteria which reported able increasing plant resistance to disease. In general, Bacillus sp. has the ability forming defensive structure i.e endospores as protector from extreme environmental conditions. In other hand, Bacillus sp. able producing antifungal compounds causing swelling of pathogenic fungus hyphae in vitro. This is effective against Foc caused wilt of banana (Hadiwiyono et al., 2013).

Plant root as the important plant part contain many of microbe. The high population of microbes living in the root and rhizosphere because they contain many amino acid and sugar as source of nitrogen and carbon needed for microbial development. Plant root also reported containing several types of endophytic bacteria living in plant tissue. Harni et al., (2012) define endophytic bacteria as microbe living or colonize plant internal tissue but do not cause interference with the host. Plant root have the highest population density of endophytic bacteria than stem and leaves. Bacillus sp. is a bacteria living in the rhizosphere and plant root with ability as biological agents and control the pathogenic microbial attack on plants. The important indicator use identified potential of Bacillus sp. as a biological agent or antagonist is to test their physiological characters (Nel et al., 2006; Kumar et al., 2012; Lin et al., 2014; Sukmadewi et al., 2015; Ploetz, 2015; Anusha et al., 2019). The purpose research is to study 
physiological character of Bacillus sp. such as: ability of bacteria produced IAA (Indole Acetic Acid), gibberelin (GA3), ability phosphate solubilizing and produce salicylic acid as biological control against Foc. The useful of the research is providing information about the potential of Bacillus sp. in increasing plant resistance against Foc.

\section{Materials and Methods}

The research was conducted from March to November 2018 located in The Agricultural Biotechnology Laboratory, Center of Research Hasanuddin University, Makassar Indonesia.

\section{Bacillus sp. isolation from rhizosphere and} roots of banana

Samples were taken from the soil at rhizosphere of healthy banana plants from various varieties produce flowers/ fruits (reproductive phase). Samples from rhizosphere about $200 \mathrm{~g}$ from soil depth 20-30 $\mathrm{cm}$. Each soil sample weighed about $1 \mathrm{~g}$, put in test tube, added $10 \mathrm{ml}$ of distilled water mixed with $0.01 \mathrm{M}_{2} \mathrm{OMgSO}_{4} .720 \mathrm{M}$. Dilution was carried out until $10^{-5}$, by an eppendorf pipette, each solution was taken $100 \mu$ then put in a petridish containing Nutrient Glucose Agar (NGA) as medium for bacteria and flattened using a spatula. The single colony obtained was purified on the same medium.

Bacillus sp. also isolated from root of the same banana plant for soil rhizosphere. Bacterial isolation in banana plant roots was carried out based on the method of Handayani et al., (2017) with modification. Approximately $1 \mathrm{~g}$ root has been washed thoroughly in running water then sterilized using $70 \%$ alcohol for 1 minute. The roots was soaked with $2 \% \mathrm{NaOCl}$ for 2 minutes, soaked with distilled water three times for 1 minute. Banana root samples was planted on
NGA to determine the presence of microbial contaminants. If within 3 days the root sample remains healthy, the sample was crushed and added $5 \mathrm{ml}$ of sterile distilled water. A total of $1 \mathrm{ml}$ of the root sample solution was put into a test tube containing $9 \mathrm{ml}$ of sterile distilled water was previously mixed with $\mathrm{MgSO}_{4} .7 \mathrm{H}_{2} \mathrm{O} 0.01 \mathrm{M}$, diluted to $10^{-5}$. Using an eppendorf pipette $100 \mathrm{ml}$ of solution was taken then put in a petridish containing NGA and flattened using a spatula. A single colony of Bacillus sp. obtained is transferred and purified using the same growing media.

\section{Ability of Bacillus sp. produced Indole Acetic Acid (IAA)}

Physiologi characterization of Bacillus sp. includes the Indole Acetic Acid (IAA) production test. IAA production was measured using the standard method by culturing Bacillus sp. derived from the rhizosphere and roots of various types of bananas. All isolates were added with $0.1 \mathrm{~g} \mathrm{~L}$ tryptophan then incubated for 48 hours in dark room with a room temperature around $27^{\circ} \mathrm{C}$. IAA produced by Bacillus sp. filtered using filter paper Whatman No. 1 then centrifuged at $3000 \mathrm{rpm}$ for 30 minutes, added 2 drops of orthophosphate acid and 4 $\mathrm{ml}$ of Salkowski reagent, stored in a dark room for 24 hours. It is expected that the color change of the solution to pink indicates the isolates tested was produced IAA. The IAA from Bacillus sp. was measured its absorption by using a spectrometer (Spectronic 20) with a wavelength of $530 \mathrm{~nm}$ (Jumjunidang et al., 2011). IAA concentrations are measured and compared with IAA standard curves. Regression curves are used observe the absorption of isolates that have been tested. Auxin concentration was measured using the IAA standard curve $\mathrm{Y}=0.064 \mathrm{x}+0.09$ where the value of $\mathrm{R}=$ 0.995 came from the IAA stock solution. 


\section{Ability of Bacillus sp. produced GA3}

Gibberelin acid (GA3) as one of important hormone produced by Bacillus sp. based on standard methods (Hadiwiyono et al., 2013). The similar source of Bacillus sp. in the IAA test was grown in NA media and incubated at room temperature around $27^{\circ} \mathrm{C}$ for 7 days. Furthermore, the media contained isolates of Bacillus sp. centrifuged at a speed of 8000 rpm for 10 minutes, pipetted as much as 15 $\mathrm{ml}$ into a test tube and added $2 \mathrm{ml}$ of zinc acetate. After 2 minutes $2 \mathrm{ml}$ of potassium ferrocyanide was added, then centrifuged at $8000 \mathrm{rpm}$ for 10 minutes. Approximately $5 \mathrm{ml}$ of the supernatant added to $5 \mathrm{ml}$ of $30 \% \mathrm{HCl}$, incubated at room temperature $27^{\circ} \mathrm{C}$ for 75 minutes. The absorbency is measured using a UV-VIS spectrophotometer $254 \mathrm{~nm}$. GA3 concentration was measured using a standard GA3 curve with regression $\mathrm{Y}=0.888 \mathrm{X}+$ $0.441, \mathrm{R} 2=0.921$ made from GA3 stock solution.

\section{Ability of Bacillus sp. as phosphate solubilizing bacteria}

Ability of Bacillus sp. as phosphate solubilizing bacteria was observed according to the method of Kristiawati et al., (2014) using Pikovskaya media. The petridish contains Pikovskaya media added with colony of Bacillus sp. to be tested. The media contain Bacillus sp. incubated for 3-7 days at room temperature. The ability to solubilize phosphate from the tested isolates was evaluated qualitatively based on the formation of clear zones around bacterial colonies.

\section{Ability of Bacillus sp. produced salicylic acid}

Analysis of salicylic acid concentration was conducted by method of Gondor et al., (2016). The absorbance was measured at wavelength $278 \mathrm{~nm}$. Salicylic acid stock solution is made with a concentration of 0.1 $\mathrm{mg} / \mathrm{ml}$ and subsequently used to make $0.001 \%$ salicylic acid stock solution. Salicylic acid measurements were carried out by weighing the soil and roots of each variety of banana plant by $0.50 \mathrm{~g}$, mashed then adding chloroform. After that, added distilled water until $100 \mathrm{ml}$. The absorbance measurements were carried out with wavelength $278 \mathrm{~nm}$.

\section{Data analysis}

Data from observations were analyzed by Combinate Analysis of Variance method in a Randomized Group Design. Data analysis techniques using combined analysis accommodate the influence variety of banana, effect of repetition, treatment and interaction between treatments. Further tests needed if the results analysis of variance indicate the interactions is real, then further tests are carried out on the interaction factors with Duncan's Multiple Range Test. If the interaction is not real then further tests are carried out on the single factor.

\section{Results and Discussion}

\section{IAA Concentration from Bacillus sp. isolation at banana rhizosphere and roots}

In vitro antagonistic bacterial testing is a common procedure performed in selecting potential strains of bacteria controlling plant diseases, especially the activity of Bacillus sp. in suppressing Foc. Qualitative IAA results on various isolates of Bacillus sp. presented in Table 1:

IAA production from Bacillus sp. with incubation period about 24 hours produced different concentrations (Table 1). PAA 2 produced the highest IAA in the range of 3.26 $\mathrm{mgl}^{-1}$ and PAA $3\left(2.67 \mathrm{mgl}^{-1}\right)$. However, PUA and PKT 3 produced the lowest IAA with a value of $1.093 \mathrm{mgl}^{-1}$ and $1.037 \mathrm{mgl}^{-1}$. It is 
suspected that difference is influenced by the ability of Bacillus sp. derived from different varieties of banana isolates results in converting tryptophan content into IAA. Putra and Giyanto (2014) reported some microbes produce hormones similar to producing by plants: auxin, cytokinins and gibberelin.

Some genera of bacteria can produce auxin or IAA, such as: Pseudomonas, Azospirillium, Azotobacter, Bacillus, Lactobacillus, Paenibacillus, Enterobacter, Serrati and Klebisiella. Sudirman et al., (2011) and Sukmadewi et al., (2015) reported that tryptophan is a precursor has functions for biosynthesis of auxins in microbes and plants. Bacillus sp. produce auxin and plants used improve the quality of their growth. The results of the analysis have been carried out indicate the Bacillus sp. known as antagonistic bacteria because inhibits the growth of pathogens as well as being endophytic.

Bacillus sp. derived from the roots and stems of banana plants, can produce IAA hormones was characterized by the formation of pink and transparent pink. The combination of $\mathrm{Fe}$ and sulfuric acid $\left(\mathrm{H}_{2} \mathrm{SO}_{4}\right)$ as a single reagent can increase sensitivity in determining IAA formation. According to Nurcahyani et al., (2018) and Faridah et al., (2018) reported that bacteria able to produce IAA will turn red when Salkowski reagents are dropped due to interactions between IAA and $\mathrm{Fe}$ to form complex compounds $\left[\mathrm{Fe}_{2}(\mathrm{OH})_{2}(\mathrm{IA})_{4}\right]$.

The color produced by bacterial antagonist isolate Bacillus sp. after addition Salkowski reagents are unstable because the color will quickly form and fade. Findings of Faridah et al., (2018) and Pegg et al., (2019) reported that Bacillus sp. produced IAA and showed a deep red color, while the pink color is an indication of the high concentration of IAA produced by them. IAA is an important part of the auxin hormone and very vital part in supporting the process of plant growth. The IAA hormone plays a very important role in plant growth because it plays an important role in the process of cell extension, apical dominance, bud growth, leaf growth/fall and flower formation.

\section{GA3 Concentration from Bacillus sp.}

The study of plant growth and development is very important because plants are strongly influenced by the availability of phytohormones such as: auxin, gibberelin and cytokinins. Gibberelin produced by plants stimulate growth and development of roots, flowers and fruit. Beside plant, phytohormones also produced from microbes, for example bacteria (Jumjunidang et al., 2011; Sukmadjaja et al., 2013). The results of the GA3 hormone test on Bacillus sp. presented in Table 2 below:

Based on the analysis results was showed that the highest concentration of GA3 at PAA 3 (4.17 $\mathrm{mgl}^{-1}$ ), PBT (4.16 $\mathrm{mgl}^{-1}$ ) and PMT 1 (4.15 $\left.\mathrm{mgl}^{-1}\right)$, respectively while the lowest concentration of GA3 was produced by PUA (4.03 $\left.\mathrm{mgl}^{-1}\right)$. Farida et al., (2018) reported the concentration of GA3 hormone produced by bacteria is still very limited related ability Bacillus sp. produced GA3.

In general, gibberelin produced by plants stimulating growth and development of roots, flowers and fruit. However, phytohormones also produced from Bacillus sp. (Jumjunidang et al., 2011; Sukmadjaja et al., 2013). PAA 3 isolates showed the highest concentration of GA3 produced by Bacillus sp. This isolate recommended as an important source of phytohormone against Foc caused wilt disease in banana. 
Table.1 The Indole Acetic Acid (IAA) Concentration from Bacillus sp.

\begin{tabular}{|c|c|}
\hline Isolate & IAA Concentration $\left(\mathbf{m g l}^{\mathbf{-}}\right)$ \\
\hline PUA 2 & 21.09 \\
\hline PKT 3 & 1.04 \\
\hline PBT & 2 \\
\hline PKT 1 & 1.76 \\
\hline PMT & 1.8 \\
\hline PMT 1 & 1.61 \\
\hline PAA 2 & 3.26 \\
\hline PAA 3 & 2.67 \\
\hline PKA 3 & 2.06 \\
\hline
\end{tabular}

PUA = Purple banana (root), PKT = Purple banana (rhizosfer), PBT = Barangan banana (rhizosfer), PMT = Sweet banana (rhizosfer), PAA: Ambon banana (root), PKA: Kepok banana (root)

Table.2 The GA3 Concentration from Bacillus sp.

\begin{tabular}{|c|c|}
\hline Isolate & GA3 Concentration $\left(\mathbf{m g l}^{-\mathbf{1}}\right)$ \\
\hline PUA 2 & 4.03 \\
\hline PKT 3 & 4.1 \\
\hline PBT & 4.16 \\
\hline PKT 1 & 4.09 \\
\hline PMT & 4.14 \\
\hline PMT 1 & 4.15 \\
\hline PAA 2 & 4.12 \\
\hline PAA 3 & 4.17 \\
\hline PKA 3 & 4.08 \\
\hline
\end{tabular}

PUA = Purple banana (root), PKT = Purple banana (rhizosfer), PBT = Barangan banana (rhizosfer), PMT = Sweet banana (rhizosfer), PAA: Ambon banana (root), PKA: Kepok banana (root)

Table.3 Ability Phosphate Solubilizing from Bacillus sp.

\begin{tabular}{|c|c|}
\hline Isolate & Ability \\
\hline PUA 2 & 8.96 \\
\hline PKT 3 & 7.35 \\
\hline PBT & 10.89 \\
\hline PKT 1 & 7.79 \\
\hline PMT & 8.47 \\
\hline PMT 1 & 7.86 \\
\hline PAA 2 & 7.42 \\
\hline PAA 3 & 4.19 \\
\hline PKA 3 & 6.98 \\
\hline
\end{tabular}

PUA $=$ Purple banana (root), PKT $=$ Purple banana (rhizosfer), PBT $=$ Barangan banana (rhizosfer), PMT $=$ Sweet banana (rhizosfer), PAA: Ambon banana (root), PKA: Kepok banana (root) 
Table.4 The Concentration Salicylic Acid from Bacillus sp.

\begin{tabular}{|c|c|}
\hline Isolate & Concentration of Salicylic Acid $\left.\mathbf{~ m g l}^{-\mathbf{1}}\right)$ \\
\hline PUA 2 & 4.55 \\
\hline PKT 3 & 4.06 \\
\hline PBT & 5.64 \\
\hline PKT 1 & 6.13 \\
\hline PMT & 7.79 \\
\hline PMT 1 & 4.26 \\
\hline PAA 2 & 4.23 \\
\hline PAA 3 & 9.42 \\
\hline PKA 3 & 3.39 \\
\hline
\end{tabular}

PUA $=$ Purple banana (root), PKT $=$ Purple banana (rhizosfer), $\mathrm{PBT}=$ Barangan banana (rhizosfer), PMT $=$ Sweet banana (rhizosfer), PAA: Ambon banana (root), PKA: Kepok banana (root)

\section{Ability Bacillus sp. as phosphate solubilizing bacteria}

The Table 3 was showed result of Bacillus sp. as phosphate solubilizing bacteria at in vitro test:

Based on the results showed that PBT isolates containing Bacillus sp. from the soil giving highest number in phosphate solubilizing $\left(10.89 \mathrm{mgl}^{-1}\right)$, followed by PUA 2 (8.96 $\mathrm{mgl}^{-}$ $\left.{ }^{1}\right)$ and PMT $\left(8.47 \mathrm{mgl}^{-1}\right)$. The lowest result in phosphate solubilizing showed at PAA 3 (4.19 $\left.\mathrm{mgl}^{-1}\right)$. Kristiawati et al., (2014) reported that bacteria from plant roots or rhizobacteria playing role as phosphate solubilizing bacteria.

They are very important in providing plant nutrition. Bacillus sp. secrete various types of organic acids (such as carboxalic acid) and reduce $\mathrm{pH}$ especially releasing phosphate bonds such as $\mathrm{Ca}_{3}\left(\mathrm{PO}_{4}\right)_{2}$ in soil. The use of Bacillus sp. as an environmentally friendly biofertilizer help reduce applied of expensive phosphate fertilizers. Phosphate solubilizing bacteria such as Bacillus sp. improving the efficiency of nitrogen fixation, the availability of $\mathrm{Fe}, \mathrm{Zn}$ through the production of plant growth promotion hormones.
Ability Bacillus sp. produced salicylic acid

The result was showed at Table 4 was showed ability of Bacillus sp. produced salicylic acid at in vitro test:

Based on the result, the concentration of Bacillus sp. the highest was found in PAA 3 $\left(9.42 \mathrm{mgl}^{-1}\right)$, PMT $\left(7.79 \mathrm{mgl}^{-1}\right)$ and PKT1 $\left(6.13 \mathrm{mgl}^{-1}\right)$, respectively. The lowest salicylic acid concentration was shown by PKA 3 (3.39 $\left.\mathrm{mgl}^{-1}\right)$. Harni et al., (2012) and Muslimah et al., (2017) reported that salicylic acid is a phenolic compound playing role in stimulating plant growth especially some physiological activities such as: photosynthesis, nitrate metabolism, ethylene production, flowering, protecting plants from stress biotic and abiotic. Phenolic compounds are aromatic ring compounds contain hydroxyl groups or functional derivatives. Phenolic compounds including secondary metabolites has important role in the regulation of plant growth, phytoalexin as a defense against pathogens and rapidly transplanted from the location or to tissues through phloem. Rhizosphere bacteria are also reported to have the ability to produce salicylic acid is an indicator that induction of the main systemic resistance induced in the root part of the life of Bacillus sp. In addition 
to increasing salicylic acid levels, several bacterial species can increase plant growth (plant growth promoting rhizobacteria (PGPR) including Bacillus pumilus, $B$. subtilis, $B$. amyloliquefaciens, $B$. circulans, $B$. megaterium, Pseudomonas aeruginosa, and $P$. fluorescens (B. fluorescens).

In conclusion based the findings of research, the conclusion is:

1. Bacillus sp. was produced the highest concentration IAA from isolate PAA 2 $\left(3.26 \mathrm{mgl}^{-1}\right)$ and the lowest PK3 (1.037 $\left.\mathrm{mgl}^{-1}\right)$.

2. Bacillus sp. was produced the highest concentration GA3 from isolate PAA 3 $\left(4.17 \mathrm{mgl}^{-1}\right)$ and the lowest PUA (4.03 $\left.\mathrm{mgl}^{-1}\right)$.

3. Bacillus sp. has highest potential in solubilizing phosphate as isolate PBT $\left(10.89 \mathrm{mgl}^{-1}\right)$ and the lowest from isolate PAA $3\left(4.19 \mathrm{mgl}^{-1}\right)$.

4. Bacillus sp. was produced the highest salicylid acid from isolate PAA 3 (9.42 $\left.\mathrm{mgl}^{-1}\right)$ and the lowest from PKA 3 (3.39 $\left.\mathrm{mgl}^{-1}\right)$.

\section{References}

Akila, R., Rajendran, L., Harish, S., Saveetha, K., Ragunchander, T., and Samiyappan, R., 2011. Combined application of botanical formulations and biological control agents for the management of Fusarium oxysporum f.sp. cubense (Foc) causing Fusarium wilt in banana. Biological Control, 57(3): 175-183.

Anusha, B. G., Gopalakrishnan, S., Naik, M. K., and Sharma, M., 2019. Evaluation of Streptomyces spp. and Bacillus spp. for biocontrol of Fusarium wilt in chickpea (Cicer arietinum L.). Archieves of Phytopathology and Plant Protection, 52(5-6): 417-422.

Deltour, P., Franca, S. C., Pereira, O. L.,
Candoso, I., de Neve, S., Debode, J., and Hofte, M., 2017. Disease suppressiveness to Fusarium wilt of banana in an agroforestry system: influence of soil characteristics and plant community. Agriculture, Ecosystem and Environment, 239: 173181.

Faridah, F., Baharuddin, Nur Amin and Nasruddin, 2018. In vitro testing of Indole Acetic Acid and Gibberellic Acid production of bacterial isolates from MO-Plus and Paenibacillus polymyxa. Asian Jr. of Microbiol. Biotech. Env. Sc., 20 (Feb. Suppl.): 580-583.

Fourie, G., Steenkamp, E. T., Gordon, T. R., and Viljoen, A., 2009. Evolutionary relationships among the Fusarium oxysporum f.sp. cubense vegetative compatibility groups. App. and Environ. Microbiol., 75(14): 4770 - 4781.

Gondor, O. K., Janda, T., Soos, V., Pal, M., Majlath, I., Adak, M. K., Balazs, E., and Szalai, G., 2016. Salicylic acid induction of flavonoid biosynthesis pathways in wheat varies by treatment. Front Plant Sci. 7: 1447.

Hadiwiyono, Widyantoro, A., and Widono, S., 2013. Bacillus antagonism toward Fusarium wilt on banana seedling originated from tissue culture. Agrosains, 15(1): 21-26.

Handayani, T., Martanti, D., Poerba, Y. S., and Witjaksono, 2017. Early detection for Fusarium wilt resistance (Foc VCG 01213/16 TR4) in local and hybrid accession of banana plants. J. Hort. Indonesia, 8(2): 88-96.

Harni, R., Supramana, Sinaga, M. S., Giyanto and Supriadi, 2012. Mechanism of endophytic bacteria in controlling Pratylenchus brachyurus on patchouli. Bul. Littro., 23(1): 102-114.

Harper, J. L., 1950. Studies in the resistance of certain varieties of banana to Panama 
disease. Plant and Soil, 2(4): $374-382$.

Hermanto, C., Jumjunidang, Yanda, R. P., and Nasir, 2013. Virulence test of Fusarium oxysporum f.sp. cubense isolates in vegetative compatibility group complex 0124 on banana. J. Hort., 23(4): $372-378$.

Jumjunidang, Hermanto, C., and Riska, 2011. Virulence of Fusarium oxysporum f.sp. cubense VCG 01213/16 on banana cv Barangan from different banana varieties and locations. J. Hort., 21(2): $145-151$.

Khan, K., Martinez-Hidalgo, P., Ice, T. A., Maymon, M., Humm, E. A., Nejat, N., sanders, E. R., Kaplan, D., and Hirsch, A. M., 2018. Antifungal activity of Bacillus species against Fusarium and analysis of the potential mechanism used in biocontrol. Front Microbiol., 9: 2363.

Kristiawati, Y., Sumardiyono, C., and Wibowo, A., 2014. Control test of Fusarium wilt of banana (Fusarium oxysporum f.sp. cubense) with phosphate acid and fosetyl-aluminium. Jurnal Perlindungan Tanaman Indonesia, 18(2): 103-110.

Kumar, P., Dubay, R. C., and Maheshwari, D. K., 2012. Bacillus strains isolated from rhizosphere showed plant growth promoting and antagonistic activity against phytopathogens. Microbiological Research, 167 (8): 493499.

Lin, Y., Du, D., Si, C., Zhao, Q., Li, Z., and Li, P., 2014. Potential biocontrol Bacillus sp. strains isolated by an improved method from vinegar waste compost exhibit antibiosis against fungal pathogens and promote growth of cucumbers. Biological Control, 71: 7-15.

Muslimah, I., Nurcahyani, E., and Zulkifli, 2017. Peroxidase enzyme activity of leaves of banana ketan plantlet (Musa paradisiaca L.) results of induced resistance of the in vitro salicylic acid. Jurnal Penelitian Pertanian Terapan, 17(2): 105-108.

Nel, B., Steinberg, C., Labuschagne, N., and Viljoen, A., 2006. Isolation and characterization of nonpathogenic Fusarium oxysporum isolates from the rhizosphere of healthy bananas plants. Plant Pathology, 55: 207 - 2016.

Nurcahyani, E., Yulianty and Suharyanto, E., 2018. In vivo study : characterization of mutants Vanilla planifolia Andrews to Fusarium wilt disease based on analysis of the lignin and the phenol content. IOSR Journal of Agriculture and Veterinary Science, 11(3): $15-18$.

Pan, M. J., Rademan, S., Kunert, K., and Hasting, J. W., 2008. Ultrastructural studies on the colonization of banana tissue and Fusarium oxysporum f.sp. cubense race 4 by the endophytic bacterium Burkholderia cepacia. Journal of Phytopathology, 145 (11-12).

Pegg, K. G., Coates, L. M., O’Neill, W. T., and Turner, D. W., 2019. The Epidemiology of Fusarium wilt of banana. Frontiers in Plant Science, 20: 1-19.

Ploetz, R. C., 2015. Management of Fusarium wilt of banana : A review with special reference to tropical race 4. Crop Protection, 73: $7-15$.

Putra, C., and Giyanto, 2014. Compatibility of Bacillus spp. and Actinomycetes as biocontrol agent for Xanthomonas oryzae pv. oryzae and growth promoter for rice. J. Fitopatol Indones., 10(5): 160-169.

Saravanan, T., Bhaskaran, R., and Muthusamy, M., 2004. Pseudomonas fluorescens induced enzymological changes in banana roots ( $\mathrm{Cv}$. Rasthali) against Fusarium wilt disease. Plant Pathology Journal, 3: $72-80$.

Sudirman, A., Sumardiyono, C., and 
Widyastuti, S. M., 2011. The biocontrol of Fusarium wilt of banana (Fusarium oxysporum f.sp. cubense) with Trichoderma sp. Jurnal Perlindangan Tanaman Indonesia, 17(1): 31-35.

Sukmadewi, D. K. T., Suharjono and Antonius, S., 2015. Uji potensi bakteri penghasil hormon IAA (Indole Acetic Acid) dari tanah rhizosfer cengkeh (Syzigium aromaticum L.). Jurnal Biotropika, 3(2): 91-94.

Sukmadjaja, D., Purnamaningsih, R., and Priyatno, T. P., 2013. In vitro selection and evaluation of banana mutants variety Ambon Kuning to Fusarium wilt disease. Jurnal AgroBiogen, 9(2): 66-76.

Svabova, L and Lebeda, A., 2005. In vitro selection for improved plant resistance to toxin-producing pathogens. J. Phytopathol., 153: $52-64$.

Warman, N. M., and Aitken, E. A. B., 2018. The movement of Fusarium oxysporum f.sp.cubense (sub-tropical race 4) in susceptible cultivars of banana. Frontiers in Plant Science, 9: 1 - 9.

\section{How to cite this article:}

Amirah Djohan, Tutik Kuswinanti, Baharuddin and Andi Nasruddin. 2020. Physiological Characters Bacillus sp. on Rhizosphere and Roots of Banana (Musa paradisiaca L.). Int.J.Curr.Microbiol.App.Sci. 9(02): 2498-2507. doi: https://doi.org/10.20546/ijcmas.2020.902.284 